\title{
Pengaruh Model Outdoor Education Terhadap Keterampilan Motorik Kasar Untuk Pendidikan Anak Usia Dini
}

\author{
Andy Supriady \\ STKIP Pasundan, Cimahi, Jawa Barat, Indonesia \\ supriadyandy@gmail.com
}

\begin{abstract}
ABSTRAK
Masa usia dini merupakan "golden age period", artinya merupakan masa emas untuk seluruh aspek pekembangan manusia, baik fisik, kognisi emosi, maupun sosial. Anak-anak dengan kemampuan bergerak yang dikembangkan dengan baik akan lebih mudah beraktivitas dan lebih mudah untuk mengikuti aktivitas-aktivitas fisik daripada anak-anak yang keterampilan bergeraknya tidak dikembangkan. Sampel penelitian diambil 15 orang anak yang berusia 4-6 tahun, dengan metode pengambilan sampel The Matching-Only Pretest-Postest Control Group Design. Data yang diperoleh dari penelitian ini diolah dengan SPSS for windows menggunakan teknik Paired Sample $t$ Test terhadap data N-Gain pada kelompok eksperimen dan kelompok kontrol. Tujuan dari penelitian ini adalah untuk mengetahui pembelajaran model Outdoor Education yang dilakukan di salah satu Preschool dan Kindergarten di Bandung yaitu HighScope dan untuk mengetahui keterampilan motorik kasar anak usia dini sebelum dan setelah diberikan perlakuan Outdoor Education Model, dan juga melihat pengaruhnya dalam peningkatan keterampilan motorik kasar mereka. Hasil penelitian menunjukkan bahwa tidak terdapat perbedaan rata-rata keterampilan motorik kasar anak yang signifikan antara pretest dan posttest pada kelompok eksperimen, tidak terdapat perbedaan rata-rata keterampilan motorik kasar anak yang signifikan antara pretest dan posttest pada kelompok kontrol, dan juga tidak terdapat perbedaan rata-rata skor $\mathrm{N}$-Gain keterampilan motorik kasar anak yang signifikan antara kelompok eksperimen dan kelompok kontrol.
\end{abstract}

Kata Kunci: Keterampilan Motorik Kasar, Model Outdoor Education

\section{ABSTRAC}

Children in their young age are entering their "Golden Age Period", it means this is their golden phase to rapidly develop all their humanity aspects, includes their phisically devlopmental, cognition, emotion, and their social aspects also. Children with maintaned motoric skills were proved have better ability to perform and are more physically active than children without maintenance. 15 children aged 4-6 years were taken as samples in this research, with the sampling method The Matching-Only Pretest-Posttest Control Group Design. Data obtained from this study treated with SPSS for windows using Paired Sample t Test against Data N-Gain techniques in the experimental and control group. The purpose of this research is to determine the learning model of Outdoor Education undertaken in one of the Preschool and Kindergarten in Bandung, HighScope and to determine the gross motor skills of early childhood before and after an Outdoor Education Model treatment is given, and also to see the impact in the improvement of their gross motor skills. The results showed that there was no significant difference in the average gross motor skills of children between pretest and posttest in the experimental group, there are no significant differences in average gross motor skills of children between pretest and posttest control group, and also there is no significant difference in average score of $N$-Gain gross motor skills of children between the experimental group and the control group.

Keyword: Gross Motor Skill, Outdoor Education Model

Alamat Korespondensi: STKIP Pasundan

(C) 2020 STKIP Pasundan

Email: supriadyandy@gmail.com

ISSN 2721-5660 (Cetak) 


\section{PENDAHULUAN}

Belajar adalah suatu proses dimana asal suatu kegiatan diubah melalui prosedur penelitian baik di laboratorium ataupun di lingkungan alam (Hilgard, 2002). Penguasaan keterampilan motorik kasar dengan aktif bergerak merupakan aspek yang penting untuk dikuasai oleh anak. Proses pembelajaran merupakan salah satu bagian dari faktor penunjang bagaimana keterampilan motorik kasar anak dapat berkembang. Woodfield mengungkapkan bahwa Gross motor skills are defined as skills that involved large, whole body movement, locomotion (traveling) and whole body stretches (Wong \& Cheung, 2010). Program pembelajaran yang tepat adalah aktivitas belajar melalui bermain lingkungan luar (outdoor education). Dengan bermain akan mampu memfasilitasi keinginan anak untuk belajar keterampilan motorik, karena dunia anak adalah bermain yang merupakan bagian penting dari aktivitas fisik anak usia dini. Bermain penting untuk pembangunan diri sendiri, karena berdampak pada aspek kognitif, fisik, sosial, dan kesejahteraan emosional anak-anak dan remaja (Stork \& Sanders, 2014). Maka dari itu, keterampilan motorik kasar anak akan meningkat secara efektif melalui aktifitas bermain.

Model outdoor education mengasah keterampilan motorik dan sosial anak dimana anak akan lebih banyak melakukan kegiatan-kegiatan yang secara tidak langsung melibatkan kerja sama antar teman dan kemampuan berkreasi. Aktivitas ini akan memunculkan proses komunikasi, pemecahan masalah, kreativitas, pengambilan keputusan, saling memahami, dan menghargai perbedaan. Permainan memiliki nilai seimbang dengan belajar karena anak dapat belajar melalui permainan (learning by playing). Upaya yang signifikan ke arah itu melalui model pembelajaran outdoor education yang dirancang dan diimplementasikan untuk meningkatkan keterampilan motorik kasar dengan memanfaatkan lingkungan sekolah sebagai sumber belajar, karena perkembangan motorik itu sendiri dipengaruhi faktor lain seperti faktor keluarga (ibu, saudara, dan status sosial ekonomi orang tua), sekolah, sosial-budaya, dan pemberian program gerak menjadi faktor yang mempengaruhi keterampilan motorik anak (Venetsanou \& Kambas, 2015; Chow \& Chan, 2011).

Maka dari itu, tujuan penelitian ini ingin melihat perbedaan pengaruh dari penerapan model outdoor education pada anak usia dini umur 3 - 5 tahun dengan anak usia dini yang belajar dengan guru seperti biasanya.

\section{METODE}

Penelitian ini adalah penelitian kuantitatif dengan menggunakan metode Experimental research. Terdapat dua Variabel dalam penelitian ini, yakni variable bebas dan variable terikat. Variable bebeas adalah model outdoor education sedangkan variaberl terikatnya keterampilan motorik kasar. Desain The Metching-Only Pretest-Posttes control Group Design. Populasi dalam penelitian ini adalah kelompok bermain umur 3 - 5 tahun di High Scope Indonesia Preschool and 
Kindergarten Bandung yang terdiri dari 2 kelas, masing-masing kelas berjumlah 15 anak sehingga jumlah keseluruhan populasi 30 siswa. Teknik pengambilan sampel dalam penelitian ini adalah total sampling dimana seluruh populasi menjadi sampel. Terdapat 30 orang anak yang dibagi ke dalam kelas yellow and purple, dimana setiap kelas berjumlah 15 orang. Kemudian dalam pemberian treatment dilakukan random assignment (Fraenkel, et al, 2012), kedua kelas diundi untuk mendapatkan treatment dan non treatment. Instrumen yang digunakan untuk mengukur keterampilan motorik kasar anak dalam penelitian ini adalah Test Gross Motor Development - Second Edition (TGMD-2 ${ }^{\text {nd }}$ Edition). (Ulrich, 2013). Pengujian hipotesis penelitian pada dasarnya ingin mengetahui pengaruh dari model outdoor education terhadap keterampilan motorik kasar anak dengan metode pre-test post-test control group design. Dengan langkahlangkah uji asumsi statistik dan uji hipotesis.

\section{HASIL DAN PEMBAHASAN}

Hasil

Perolehan rata-rata dan standar deviasi keterampilan motorik kasar anak pada saat pretest dan posttest pada kelompok eksperimen dan kelompok control disajikan pada tabel 3.1.

Tabel 1.

Perolehan Rata-rata TGMD-2

\begin{tabular}{|l|l|c|c|}
\hline Test & \multicolumn{1}{|c|}{ Kelompok } & Pretest X & Posttest X \\
\hline \multirow{2}{*}{ Motorik kasar } & Eksperimen & 52,33 & 66,53 \\
\cline { 2 - 4 } & Kontrol & 52,8 & 62,8 \\
\hline
\end{tabular}

Berdasarkan rata-rata motorik kasar pada kelompok eksperimen dan kelompok kontrol terlihat bahwa masing-masing kelompok menunjukan peningkatan. Pada kelompok eksperimen, motorik kasar anak pada saat pretest $(X=52,33)$ meningkat menjadi $(X=66,53)$ pada saat posttest. Begitu pada kelompok kontrol, pada saat pretest rata-rata motorik kasar (X=52,8) meningkat menjadi $(X=62,8)$.

Sementara itu Uji asumsi statistik yang diajukan untuk menguji hipotesis pertama, kedua dan ketiga yakni uji normalitas dan homogenitas data. Uji normalitas dilakukan pada data pretest dan posttest pada kelompok eksperimen dan kelompok kontrol.

Pengujian normalitas (Test of normality) dilakukan dengan menggunakan Uji Kolomogrov Smirnov pada taraf signifikan $\alpha=0,05$. Pedoman pengambilan keputusan adalah :

○ Bila nilai signifikan atau nilai probabilitas $P<0,05$ (distribusi tidak normal, akan tetapi

○ Bila nilai signifikan atau nilai probabilitas $P>$ (distribusi normal) 
Tabel 2.

Hasil Uji Normalitas Data

Tests of Normality

\begin{tabular}{|ll|r|r|c|}
\hline \multirow{2}{*}{ KELOMPOK } & \multicolumn{3}{|c|}{ Kolmogorov-Smirnov } \\
\cline { 3 - 5 } & & Statistic & df & Sig. \\
\hline PRE & 1.00 & .130 & 15 & $.200^{*}$ \\
POST & 1.00 & .114 & 15 & $.200^{*}$ \\
\hline
\end{tabular}

Dari hasil uj normalitas (Test of Normality) pada tabel di atas menunjukan bahwa, nilai signifikan/P dalam kolom kolomogrov-Smirnov untuk pretest kelompok eksperimen dan kelompok kontrol masing-masing 0,200 dan 0,200, sedangkan nilai signifikan untuk posttest kelompok eksperimen dan kelompok kontrol masing-masing 0,200 dan 0,200. Kemudian nilai signifikan atau probabilitas N-Gain pada kelompok eksperimen dan kelompok kontrol masingmasing 0,200 dan 0,200. Data hasil pretes, posttest,dan N-Gain dari kelompok eksperimen dan kelompok kontrol nilai signifikan atau nilai probabilitas > dari 0,05, ini berate data hasil pretest dan posttest pada kelompok eksperimen dan kelompok kontrol adalah normal. Maka pengujian selanjutnya menggunakan statistik parametrik.

Selanjutnya pengujian kesamaan ragam (Homogenity of Variances) dengan menggunakan Lavene tes, dengan kriteria keputusan adalah sebagai berikut :

- Bila nilai signifikan atau nilai probabilitas $<0,05$, data yang berasal dari populasi memiliki variansi tidak sama (tidak homogen)

- Bila nilai signifikan atau nilai probabilitas $>0,05$, data berasal dari populasi memiliki varians sama (homogen)

Tabel 3.

Uji Homogenitas

Test of Homogeneity of Variance

\begin{tabular}{|c|c|c|c|c|c|}
\hline & & Levene Statistic & df1 & df2 & Sig. \\
\hline \multirow{4}{*}{ EKSPERIMEN } & Based on Mean & 498 & 1 & 28 & .486 \\
\hline & Based on Median & .557 & 1 & 28 & .462 \\
\hline & Based on Median and & .557 & 1 & 27.967 & .462 \\
\hline & $\begin{array}{l}\text { Based on trimmed } \\
\text { mean }\end{array}$ & .476 & 1 & 28 & 496 \\
\hline
\end{tabular}

Interpretasi dilakukan dengan memilih salah satu statistic, yaitu statistic yang didasarkan pada rata-rata (based on mean). Didapatkan nilai signifikan based on mean untuk pretest $\alpha 0,05$ maka data pretest $t$ memiliki varian yang sama atau homogen. 
Dapat ditarik kesimpulan bahwa distribusi data normal dan homogen, maka pengujian dilakukan dengan analisis statistik parametrik.

Tahap berikutnyanya adalah pengujian hipotesis penelitian. Pengujian hipotesis pertama mengenai perbedaan rata-rata keterampilan motorik kasar anak antara pretest dan posttest pada kelompok eksperimen. Teknik analisis yang digunakan untuk menguji hipotesis ini adalah dengan paired sample $t$ test, yakni membandingkan rata-rata keterampilan motorik kasar anak antara pretest dan posttest pada kelompok eksperimen.

Hipotesis :

Ho : Tidak terdapat perbedaan rata-rata keterampilan motorik kasar anak antara pretest dan posttest pada kelompok eksperimen.

Ha : Terdapat perbedaan rata-rata keterampilan motorik kasar anak antara pretest dan posttest pada kelompok eksperimen.

Dengan kriteria apabila $\mathrm{t}$ hitung $>\mathrm{t}$ tabel $(\mathrm{dk}-1,0,05)$ maka Ho ditolak dan sebaliknya apabila thitung $<\mathrm{t}$ tabel $(\mathrm{dk}-1,0,05)$ maka Ho diterima.

Disamping menggunakan $\mathrm{t}$ hitung dengan $\mathrm{t}$ tabel, dapat juga melakukan perbandingan nilai probabilitas atau sig. dengan $\alpha(0,05)$ dengan kriteria apabila probabilitas/sig. $<0,05$ maka Ho ditolak dan apabila probabilitas/sig.> 0,05 maka Ho diterima.

Tabel 4.

Paired Samples Test

\begin{tabular}{|lr|r|r|r|r|}
\hline & Paired Differences & \multicolumn{1}{c|}{$\mathrm{t}$} & \multicolumn{1}{c|}{$\mathrm{df}$} & Sig. (2-tailed) \\
\hline Pair 1 PRE_EX - POST_EX & 25.40739 & 8.595 & 14 & .000 \\
\hline
\end{tabular}

Berdasarkan tabel di atas, diketahui bahwa nilai t hitung $(8,595)>t$ tabel $(2,145)$, maka Ho ditolak. Dapat diartikan Terdapat perbedaan rata-rata keterampilan motorik kasar anak antara pretest dan posttest pada kelompok eksperimen.

Selanjutnya, pengujian hipotesis yang kedua mengenai perbedaan rata-rata keterampilan motorik kasar anak antara pretest dan posttest pada kelompok kontrol. Teknik analisis yang digunakan untuk menguji hipotesis ini adalah dengan paired sample t test, yakni membandingkan rata-rata keterampilan motorik kasar anak antara pretest dan posttest pada kelompok kontrol. Hipotesis :

Ho : Tidak terdapat perbedaan rata-rata keterampilan motorik kasar anak antara pretest dan posttest pada kelompok kontrol.

Ha : Terdapat perbedaan rata-rata keterampilan motorik kasar anak antara pretest dan posttest pada kelompok kontrol. 
Dengan kriteria apabila t hitung $>\mathrm{t}$ tabel $(\mathrm{dk}-1,0,05)$ maka Ho ditolak dan sebaliknya apabila thitung $<\mathrm{t}$ tabel $(\mathrm{dk}-1,0,05)$ maka Ho diterima.

Disamping menggunakan $\mathrm{t}$ hitung dengan $\mathrm{t}$ tabel, dapat juga melakukan perbandingan nilai probabilitas atau sig. dengan $\alpha(0,05)$ dengan kriteria apabila probabilitas/sig. $<0,05$ maka Ho ditolak dan apabila probabilitas/sig.> 0,05 maka Ho diterima.

Tabel 5.

Paired Samples Test

\begin{tabular}{|ll|r|r|r|r|}
\hline & \multicolumn{1}{|c|}{$\begin{array}{c}\text { Paired } \\
\text { Differences }\end{array}$} & \multicolumn{1}{c|}{$\mathrm{T}$} & $\mathrm{df}$ & Sig. (2-tailed) \\
\hline Pair 1 & PRE_CON - POST_CON & 21.58684 & 4.814 & 14 & .000 \\
\hline
\end{tabular}

Berdasarkan tabel di atas, diketahui bahwa nilai t hitung $(4,814)>t$ tabel $(2,145)$, maka Ho ditolak. Dapat diartikan Terdapat perbedaan rata-rata keterampilan motorik kasar anak antara pretest dan posttest pada kelompok kontrol.

Pengujian hipotesis yang ketiga mengenai perbedaan rata-rata skor N-Gain keterampilan motorik kasar anak antara kelompok eksperimen dan kelompok kontrol. Untuk pengujian hipotesis yang kedua menggunakan teknik independent sample t test dengan membandingkan NGain (rata-rata posttest dikurangi rata-rata pretest) pada kedua kelompok.

Hipotesis :

Ho : Tidak terdapat perbedaan skor N-Gain pada keterampilan motorik kasar anak yang signifikan antara kelompok eksperimen dan kelompok kontrol

Ha : Terdapat perbedaan skor N-Gain pada keterampilan motorik kasar anak yang signifikan antara kelompok eksperimen dan kelompok kontrol

Dengan kriteria apabila $\mathrm{t}$ hitung $>\mathrm{t}$ tabel $(\mathrm{dk}-1,0,05)$ maka Ho ditolak dan sebaliknya apabila thitung $<\mathrm{t}$ tabel $(\mathrm{dk}-1,0,05)$ maka Ho diterima.

Disamping menggunakan $\mathrm{t}$ hitung dengan $\mathrm{t}$ tabel, dapat juga melakukan perbandingan nilai probabilitas atau sig. dengan $\alpha(0,05)$ dengan kriteria apabila probabilitas/sig. $<0,05$ maka Ho ditolak dan apabila probabilitas/sig.> 0,05 maka Ho diterima. 
Tabel 6.

Independent Samples Test

\begin{tabular}{|c|l|r|r|r|r|}
\hline \multicolumn{2}{|c|}{} & F & Sig. & T & \multicolumn{1}{c|}{ df } \\
\hline \multirow{3}{*}{ N_GAIN } & Equal variances assumed & .465 & .501 & 1.384 & 28 \\
\cline { 2 - 6 } & $\begin{array}{l}\text { Equal variances not } \\
\text { assumed }\end{array}$ & & & 1.384 & 26.168 \\
\hline
\end{tabular}

Berdasarkan tabel 4.7. diketahui bahwa nilai t hitung $(1,384)<t$ tabel ${ }_{(15 ; 0,05)}$ adalah $(2,045)$. Selain itu nilai Probabilitas / Sig. $(0,501)>\alpha(0,05)$ Ho diterima. Jadi tidak terdapat perbedaan rata-rata $\mathrm{N}$-Gain / peningkatan keterampilan motorik kasar kelompok eksperimen dan kelompok kontrol. Dengan begitu treatment berupa model outdoor education yang diberikan selama tiap 60 menit tiap pertemuan selama 8 minggu tidak lebih berpengaruh secara signifikan terhadap keterampilan motorik kasar anak dibanding dengan model pembelajaran Preschool and Kindergarten seperti biasa oleh guru.

\section{Pembahasan}

Program model outdoor education ini berisi permainan-permainan yang dimodifikasi dari olahraga permainan dan permainan sederhana yang memiliki tema untuk mengembangkan motorik kasar anak. Pada setiap pertemuannya, dipilih permainan-permainan berdasarkan skill yang diharapkan dapat dikuasai anak. Bermain sangat penting bagi anak, penting bagi pertumbuhan dan perkembangan anak. Anak-anak harus bermain agar dapat mencapai perkembangan yang optimal. Donnelly, et al (2015) menyatakan bahwa "Children's play is a primary means by which they learn about their bodies and movement capabilities". Bermain bagi anak-anak merupakan sasaran utama dimana mereka belajar tentang tubuh dan dengan bermain juga akan dapat meningkatkan keterampilan gerak, menyalurkan hasrat bergerak dan menciptakan. Program yang berisi permainan-permainan yang sesuai dengan depelopmentally appropriate practice memang dapat memberikan pengaruh terhadap peningkatan motorik kasar anak, seperti pada penelitian yang dilakukan Bakhtiar, et al (2010) di Teheran, Iran yang mengungkapkan bahwa selected exercise yang diberikan kepada 20 anak selama delapan minggu, satu minggu tiga pertemuan yang signifikan terhadap keterampilan motorik kasar yang dinilai melalui instrument TGMD-2 dibanding dengan 20 siswi yang menjadi kelompok kontrol.

Selain itu penelitian lainnya yang dilakukan Wang (2011) menemukan bahwa treatment yang diberikan kepada 60 anak usia 3-5 tahun terbukti berhasil meningkatkan motorik kasar anak $(\mathrm{p}<0,05)$ secara signifikan pada kelompok eksperimen dibanding kelompok kontrol. 
Kemudian pada penelitian Gustiana (2010) ditemukan bahwa permainan modifikasi memberikan pengaruh yang signifikan terhadap kemampuan motorik kasar dan kognitif anak usia dini serta proses pembelajaran lebih menyenangkan dan partisipatif. Dengan demikian, pembelajaran dengan permainan modifikasi dapat dipertimbangkan sebagai alternatif pembelajaran penjas untuk anak usia dini.

Faktor lain yang menyebabkan tidak adanya perbedaan pengaruh model outdoor education terhadap keterampilan motorik kasar anak usia dini karena adanya faktor lain yaitu faktor biologis dan pola asuh, tentang faktor yang menghambat atau mendukung perkembangan kemampuan psikomotor anak. Faktor genetik atau kondisi media dapat mempengaruhi kemampuan motorik anak. Contoh: jika orang tua memiliki sebab genetis kelemahan otot, maka anak juga akan mengalami gangguan motoris otot; atau pada anak dengan autis biasanya sangat sulit meningkatkan kemampuan motoriknya karena kelainan pada kondisi tubuhnya. Faktor pola asuh orang tua yang otoriter ataupun terlalu memaksa anak di luar kemampuannya. Apabila orangtua memaksakan peningkatan atau latihan kemampuan psikomotor anak, kebanyakan malah akan merasa canggung, takut salah hingga tidak percaya pada diri sendiri serta merasa tertekan.

Keterampilan motorik kasar anak merupakan hal yang penting karena keterampilan ini merupakan dasar bagi anak untuk menguasai keterampilan yang lebih kompleks, dengan menguasai keterampilan yang lebih kompleks, diharapkan anak akan ikut terlibat dalam aktivitas fisik seperti olahraga sehingga terwujud active life style dalam rangka meningkatkan kualitas hidup anak itu sendiri dan lebih lanjut meningkatkan kualitas hidup bangsa dimasa yang akan datang. Solusinya diperlukan suatau program yang tepat untuk mengembangkan keterampilan motorik kasar untuk pendidikan anak usia dini.

Faktor-faktor yang menghambat keterampilan motorik kasar anak usia dini harus segera ditanggulangi dengan lebih baik dan diubah menjadi faktor pendukung perkembangan motorik kasar anak usia dini. Hal yang bisa dilakukan saat ini adalah mengsinkronisasikan antara program perkembangan motorik kasar yang sudah ada dengan memberikan pemahaman lebih dan melibatkan peran orangtua untuk pembelajaran perkembangan motorik anak usia dini.

\section{KESIMPULAN}

Berdasarkan hasil penelitian dan pembahasan, maka dapat disimpulkan bahwa :

- Tidak terdapat perbedaan rata-rata keterampilan motorik kasar anak yang signifikan antara pretest dan posttest pada kelompok eksperimen.

- Tidak terdapat perbedaan rata-rata keterampilan motorik kasar anak yang signifikan antara pretest dan posttest pada kelompok kontrol. 
- Tidak terdapat perbedaan rata-rata skor N-Gain keterampilan motorik kasar anak yang signifikan bahwa kelompok eksperimen lebih baik dibandingkan dengan kelompok kontrol.

\section{DAFTAR PUSTAKA}

Bakhtiar, et. al. (2010) Effects of Selected Exercises on Elementary School Third Grade Dirl Students' Motor Development. Asian Journal of Sports Medicine. 2, (1), 52-56.

Chow, B.C. \& Chan, Lily. (2011). Gross Motor Skills of Hong Kong Preschool Children. Asian Journal of Physical Education \& Recreation, 17, (1), 71-77.

Donnelly, F. C., et al. (2017). Developmental physical education for all children: theory into practice (5th ed.). Champaign, IL: Human Kinetics.

Fraenkel, J. R., et al. (2012). How to Design and Evaluate Research in Education. (8th eds). New York: McGraw-Hill Inc.

Gustiana, Asep Deni. (2011). Pengaruh Permainan Modifikasi terhadap Motorik Kasar dan Kognitif Anak Usia Dini. Tesis pada SPs UPI: tidak diterbitkan.

Hilgard, Ernest R. (2002). Conditioning and Learning. The American Journal of Psychology. 62, (3), $453-456$.

Stork, S., \& Sanders S. W. (2014). Physical Education in Early Childhood. The Elementary School Journal. 108, (3), 197 - 206.

Ulrich, D A (2013). Test of Gross Motor Development. 2nd ed. Austin, TX: Pro-Ed.

Venetsanou \& Kambas (2015). Environmental Factor Affecting Preschoolers' Motor Development. Journal of Early Childhood Education. 37, 319-327.

Wang, Joanne H.T (2011). A Study on Gross Motor Skill of Preschool Children. Journal of Research in Childhood Education. 19, (1), 32-43.

Wong, K. Y. A. dan Cheung, S. Y. (2010). Confirmatory Factor Analisys of Test of Gross Motor Development-2. Journal of Measurement in Physical Education and Exercise Science, 14, 202-209. 